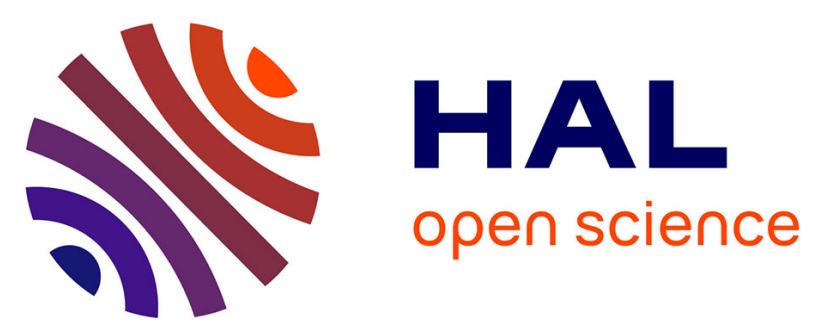

\title{
Broad-band electric field measurements above thunderstorms by the IME-HF instrument prepared for the TARANIS mission
}

Ondřej Santolík, Ivana Kolmašová, Radek Lán, Luděk Uhlír, Jean-Louis Rauch, Aude-Lyse Millet, Jean-Louis Pincon

\section{To cite this version:}

Ondřej Santolík, Ivana Kolmašová, Radek Lán, Luděk Uhlír, Jean-Louis Rauch, et al.. Broad-band electric field measurements above thunderstorms by the IME-HF instrument prepared for the TARANIS mission. 22nd EGU General Assembly, 2020, Online, France. 10.5194/egusphere-egu2020-15159 . insu- 03560748

\section{HAL Id: insu-03560748 \\ https://hal-insu.archives-ouvertes.fr/insu-03560748}

Submitted on 8 Feb 2022

HAL is a multi-disciplinary open access archive for the deposit and dissemination of scientific research documents, whether they are published or not. The documents may come from teaching and research institutions in France or abroad, or from public or private research centers.
L'archive ouverte pluridisciplinaire HAL, est destinée au dépôt et à la diffusion de documents scientifiques de niveau recherche, publiés ou non, émanant des établissements d'enseignement et de recherche français ou étrangers, des laboratoires publics ou privés.

\section{(c)(1)}

Distributed under a Creative Commons Attribution| 4.0 International License 
EGU2020-15159, updated on 08 Feb 2022

https://doi.org/10.5194/egusphere-egu2020-15159

EGU General Assembly 2020

(c) Author(s) 2022. This work is distributed under

the Creative Commons Attribution 4.0 License.

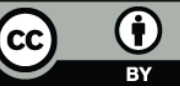

\title{
Broad-band electric field measurements above thunderstorms by the IME-HF instrument prepared for the TARANIS mission
}

\author{
Ondřej Santolík ${ }^{1,2}$, Ivana Kolmašová1,2, Radek Lán ${ }^{1}$, Luděk Uhlír ${ }^{1}$, Jean-Louis Rauch ${ }^{3}$, Aude-Lyse \\ Millet $^{3}$, and Jean-Louis Pincon ${ }^{3}$ \\ ${ }^{1}$ Institute of Atmospheric Physics of the Czech Academy of Sciences, Department of Space Physics, Prague, Czechia \\ (os@ufa.cas.cz) \\ ${ }^{2}$ Faculty of Mathematics and Physics, Charles University, Prague, Czechia \\ ${ }^{3}$ LPC2E/CNRS, Orleans, France
}

\begin{abstract}
A broad-band analyzer of the IME-HF instrument ("Instrument de Mesure du champ Electrique Haute Frequence") is prepared for the TARANIS (Tool for Analysis of RAdiation from lightNIng and Sprites) micro-satellite of the French space agency CNES. The spacecraft is based on the MYRIADE series platform. It will be launched on a Sun synchronous polar orbit at $700 \mathrm{~km}$ altitude. TARANIS will carry a complex payload of six scientific instruments to study radiation from lightning and optical phenomena (Transient Luminous Events) observed at altitudes between 20 and $100 \mathrm{~km}$ (blue jets, red sprites, halos, elves). The scientific instruments onboard TARANIS will detect electromagnetic radiation from very low frequencies up to $37 \mathrm{MHz}$, optical radiation, $\mathrm{X}$ rays (with an aim to study the Terrestrial "Gamma-ray" Flashes), and energetic electrons.
\end{abstract}

The IME-HF instrument will record waveform measurements of fluctuating electric fields in the frequency range from a few $\mathrm{kHz}$ up to $37 \mathrm{MHz}$, with the following scientific aims: (i) Identification of possible wave signatures associated with transient luminous phenomena during storms; (ii) Characterization of lightning flashes from their HF electromagnetic signatures; (iii) Identification of possible HF electromagnetic or/and electrostatic signatures of precipitated and accelerated particles; (iv) Determination of characteristic frequencies of the medium using natural waves properties; (v) Global mapping of the natural and artificial waves in the HF frequency range, with an emphasis on the transient events. The instrument will be also able to trigger and record interesting intervals of data using a flexible event detection algorithm. 